\section{HEA reauthorization}

The Higher Education Act (HEA) will expire in September 1997. The leadership of the House Committee on Economic and Educational Opportunities (renamed the House Committee on Education and the Work Force) and its Subcommittee on Postsecondary Education, Training and Lifelong Learning sent a letter to the higher education community asking for input and participation in the reauthorization process. Specifically, the letter asked for "proposals to maintain and expand access to higher education, promote quality educational opportunities, address the rising costs of higher education, simplify student aid and institutional aid programs, promote student academic preparation for postsecondary education, and promote savings for postsecondary education."

A broad coalition of higher education organizations has organized task forces to consider current HEA programs, which ones are likely to receive serious consideration in the current political climate, and what changes the higher education community should jointly recommend. The American Council on Education coordinates this effort, which concentrates on HEA student aid provisions, plus selected other titles of HEA that have received significant funding in recent years. Congress is expected to continue its recent trend of not renewing programs with little or no recent funding history.

Consistent with this trend, the parts of the HEA Title II library programs that were continuing to receive funding (some research and demonstration projects plus a small amount of fellowship and training assistance) were included in last fall's Library Services and Technology Act as part of a new national leadership program in the library field (along with preservation and digitization and joint library/museum projects). At the same time, HEA II was repealed, so it will not be among the parts of HEA in the reauthorization process, nor is it

Lynne E. Bradley is deputy executive director of ALA's Washington Office; e-mail: leb@alawash.org. the subject of an HEA task force among higher education groups.

The AlA Washington Office has been monitoring or participating in task force meetings as appropriate, especially on the College Work Study Program, and expects to be supporting the higher education community in joint recommendations

The American Council on Education (ACE) includes a list of task forces, their efforts, and contacts for them on its Web site: http://www.acenet.edu/Programs/DGR/ taskforces.HTML. Librarians are encouraged to call any or all of these individuals with ideas or suggestions for reauthorization proposals, or contact ACE at One Dupont Circle, Washington, DC 20036.

\section{INTERNET II}

The Next Generation Internet and Internet II represent a very important and evolving policy area especially for the academic and research communities. There have been many policy concerns directed to the limitations and strains on the current Internet and three related developments are being watched for increased congressional attention:

First, a number of research universities announced the formation of a consortium to develop and implement Internet II.

Second, the National Science Foundation (NSF) has announced the expansion and redirection of its vBNS (very high speed backbone network services) program.

And third, President Clinton has announced a Next Generation Internet (NGI) initiative (he mentioned this in his recent State of the Union address). The three efforts are closely related, although precisely how they will evolve and coordinate is still under discussion. The congressional science authorization and appropriation committees are likely to follow these developments closely. Whether any new legislation will be introduced is less clear. Internet II and the NGI developments are important areas for academic librarians to monitor and about which to inform other campus officials. 


\section{Metalluryical \& Materials Transactions}

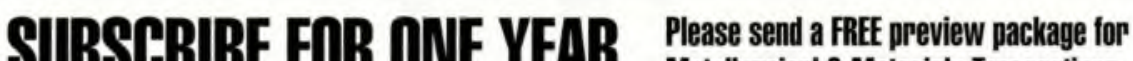

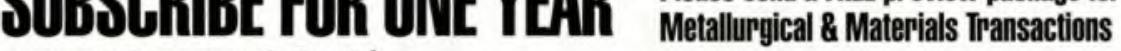 AND SAVE 20\%* \\ Name}

These two editions of archival, peerreviewed articles include the most up-to-date original materials research available.

Edition "A"

presents Physical

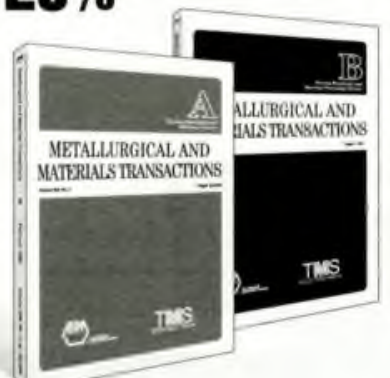

Title

Company Name

Address

City

State__ ZIP__ Country

Metallurgy and Materials Science.

Edition "B" covers Materials Processing. Both are subject indexed.

*First-time subscribers only. Mail this coupon now or call 1-800-336-5152 for your FREE preview.

Phone

Fax

E-mail

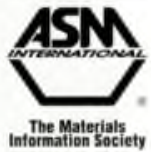

\section{C\&RL News 30th anniversary quiz}

Here is the next installment of the GERL News 30 th anniversary quiz. Test your recollection of events that have been reported in the News since 1966.

1. What was the ALA's 1992 campaign slogan promoted during National Library Week?

2. Name a science fiction writer whose photo appeared on the cover of CERL Neus.
3. The world's largest collage is located at which university library?

4. What library acquired the papers of Nobel Prize-winning author Isaac Bashevis Singer in the mid-' 90 s?

5. In the 1960s the Library of Congress acquired an unknown and unpublished autographed letter of Benjamin Franklin's in which he refers to a musical instrument that he invented. Name the instrument.

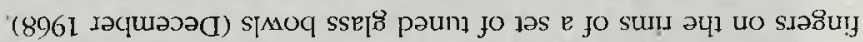

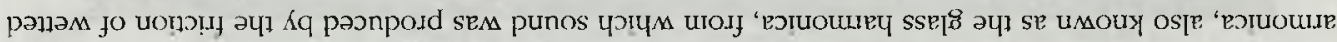

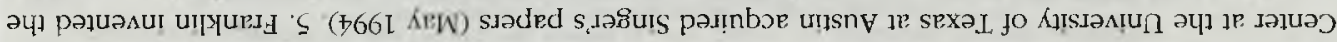

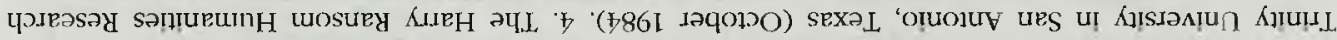

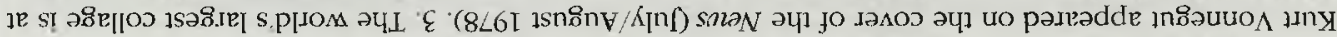

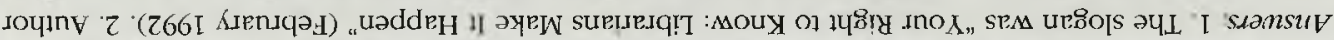


THEY LEARN ABOUT THEM IN BIOLOGY.

THEY LEARN ABOUT THEM IN HEALTH.

THEY LEARN ABOUT THEM AT HOME.

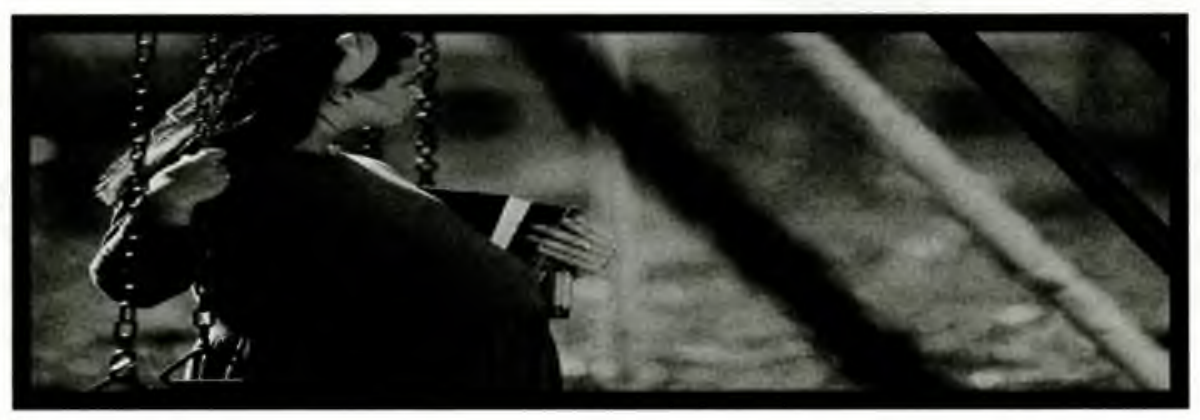

\section{AND THIS YEAR, OVER ONE MILLION TEENAGERS WILL LEARN ABOUT BABIES ON THEIR OWN.}

Many Americans support sex education in the school system. Others believe it's solely a parent's responsibility. But as the controversy escalates, so does the number of teen pregnancies.

You can explore all sides of this and other important public and social policy issues through PAIS International. PAIS gives you instant access to an index of some 400,000 hard-to-find articles, books, government documents, 1112

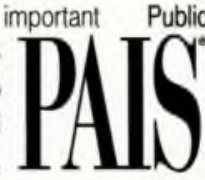

statistical directories, and more. It references literature from 60 countries around the globe.

So if you're looking for information, don't fool around. Use PAIS.

Public Affairs Information Service, Inc.

521 West 43rd Street, New York, NY 10036-4396 800-288-PAIS, 212-736-6629, FAX: 212-643-2848 e-mail: inquiries@pais.org WWW: http://Www.pais.org

NO ONE LOOKS AT THE WOALO LIKE PAIS

\section{Now available: Pais Select, our new full-text CD-rom. STOP BY ACRL CONFERENCE BOOTH \#708 FOR A DEMO.} On CD-ROM: PAIS ON CD.AOM - PAIS SELECT FULL-TEXT * PAIS INTERNATIONAL ON SILVERPLATTER , PAIS/EBSCO CD
In Print: PAIS INTEPNATIONAL IN PAINT ONIIne through: DATASTAR . DIALOG.

EBSCOHOST - INFOTRAC SEARCHBANK. OCLC. OVID - RLG On Magnetic Tape: CONTACT PAIS FOR INFORMATION 

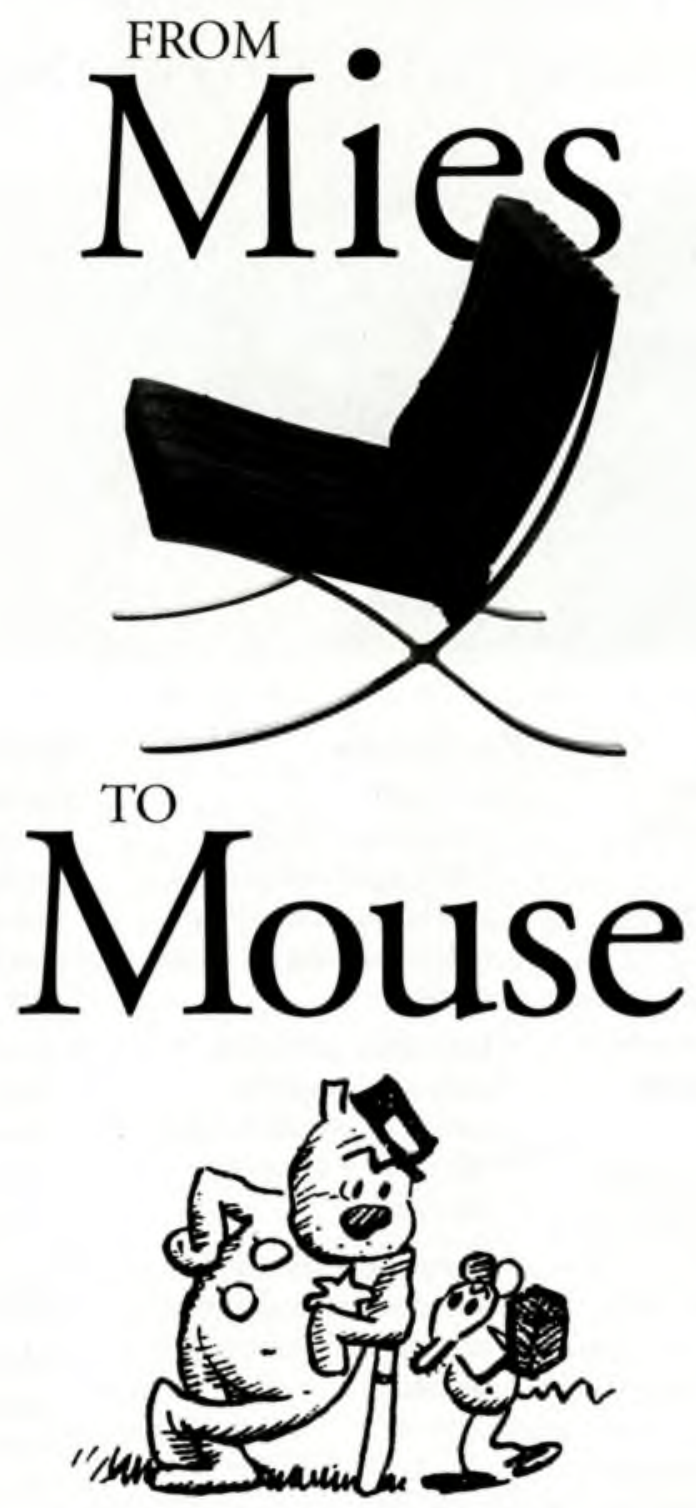

\section{The Dictionary of Art}

\section{THE UlTIMATE AUTHORITY}

on all the visual arts

34 VOLUMES $\bullet 6,700$ SCHOLARS

15 YEARS IN THE WRITING $\bullet \$ 8,800$

FOR MORE INFO CALL 800.336.0055 OR IN NY 212.647.0182 FAX: 212.647.0290 E-MAIL: DICTARTEPIPELINECOM WWW.GROVEARTMUSIC.COM MIES: The Mies van der Robe Collection, Barcelona Chair, courtesy of Knoll, MOUSE: O King Fearures Syndicate 


\section{WHY DO 6,000 LIBRARIES IN 44 Countries use OCLC FirstSearch?}

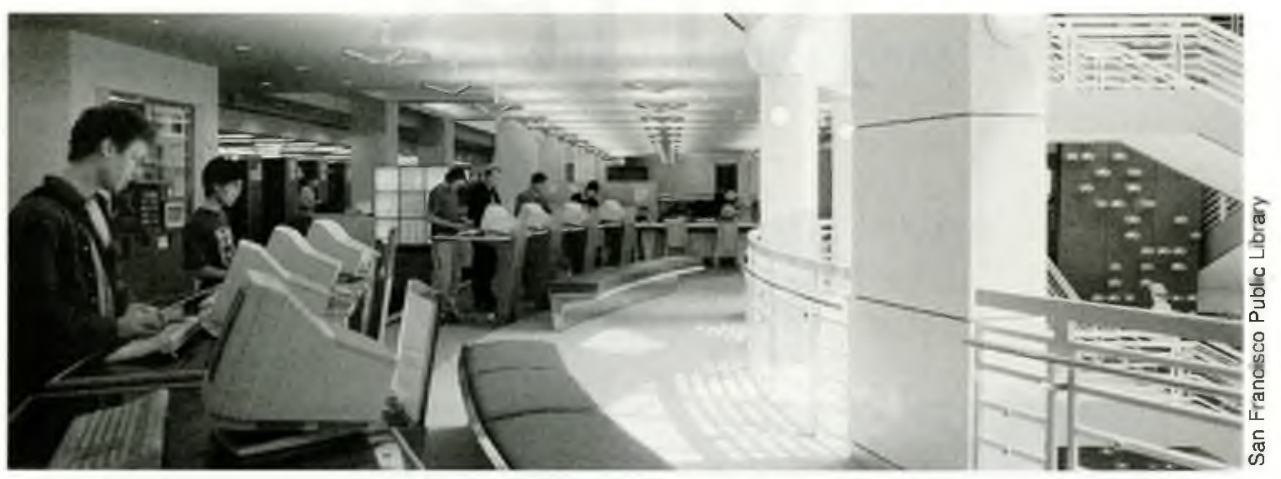

FIRSTSEARCH

\section{Comprehensiveness}

- oclc World Cat, the most frequently consulted database in higher education

- New York Times, the most recent 90 days of articles with abstracts since 1994

- Firstsianch Ca Student Edition, a customized Chemical Abstract Services collection for undergraduates (coming in 1997)

- OCLC FirstSearch Electronic Collections ONLINE, a critical mass of scholarly journal articles (coming in 1997)

- OCLC NeTFirst, unparalleled subject access to Internet resources

- Nearly 60 other databases covering humanities, science, social studies and more

\section{FiRSTSEARCH}

Fuli-Text

- More than 1 million newspaper and journal articles for immediate online viewing or e-mail delivery

- Electronic reference files: encyclopedias, almanacs, phone books, directories, financial reports

- Patron generated fulltext document delivery via interlibrary loan, fax and mail

http://www.oclc.org/

\section{FirstSearch}

FlexibIIITTY

- Seamless integration with your collection, LAN, Web services, ILL, online full text and document delivery

- Mix and match databases, full text, access level and payment plans to best serve the needs of your users

- Choice of TTYY, Web or Z39.50 interface options

- Affordable pricing options: per-search or subscription, individual or group

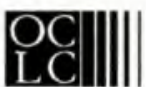

